\title{
EVALUATION OF SOX2 AS A POTENTIAL STEM CELL MARKER IN BENIGN AND MALIGNANT ODONTOGENIC TUMORS
}

\author{
Amal M. Sobhy ${ }^{1 *} B D S$, Hamed M.A. Fouad ${ }^{2} P h D$, Sahar M. Riad ${ }^{2} P h D$, Ibrahim M. \\ Zaitoun $^{3} P h D$
}

\begin{abstract}
INTRODUCTION: Odontogenic tumors (OTs) constitute a wide range of lesions derived from the tooth forming apparatus and its remnants. These tumors are generally benign, yet some are aggressive and have locally invasive behavior with a high rate of recurrence and some are malignant. Tumor stem cells (TSCs) are a unique subpopulation of cells that possess the ability to initiate a neoplasm and sustain self-renewal. Epithelial stem cell (ESC) markers such as sex-determining region Y (SRY)-box 2 (SOX2) are capable of identifying these stem cells which are expressed during the early stages of tooth development.

OBJECTIVES: To evaluate immunohistochemically the expression of the stem cell proliferating marker SOX2 in benign and malignant epithelial odontogenic tumors.

MATERIAL AND METHODS: Immunohistochemical (IHC) study using the SOX2 antibody was done on 30 surgical specimens of benign and malignant epithelial OTs as study group and 5 normal tooth germ tissues as a control group.

RESULTS: Malignant OTs biopsies showed intense immune-reactivity to SOX2, while aggressive benign OTs showed medium immunereactivity with variable intensity. Totally benign tumors were immune-negative. The IHC staining intensity was directly proportional to the state of malignancy of odontogenic tumors. The difference in the expression of SOX2 in malignant and benign OTs was statistically significant. However, the difference in the expression of SOX2 in OTs and control group was not statistically significant in mean of area percent, while it was statistically significant in mean of optical density.
\end{abstract}

CONCLUSIONS: SOX2 is highly expressed in malignant OTs biopsies. Medium immune-reactivity with variable intensities is seen in aggressive benign OTs.

KEYWORDS: Odontogenic tumors, SOX2, Stem cells, ameloblastic carcinoma. RUNNING TITLE: Tissue Expressions of SOX2 in OTs.

1 Dentist at Alexandria Police Hospital, Alexandria, Egypt.

2 Professor of Oral Pathology Department, Faculty of Dentistry, Alexandria University

3 Professor in Cranio-Maxillofacial and Plastic Surgery, Faculty of Dentistry, Alexandria University

*Corresponding author:

E-mail: mysweetheart_1988@hotmail.com

\section{INTRODUCTION}

Odontogenic tumors compromise a large heterogenous group of lesions originating from the remnants of odontogenic epithelium or ectomesenchyme (1). They include lesions with hamartomatous nature such as odontomas. Some of benign tumors are aggressive due to their recurrence and bone destruction caused by their substantial growth (1). Malignant neoplasms capable of sending metastasis such as ameloblastic carcinoma, malignant ghost cell tumors and clear cell odontogenic carcinoma (1-3).

Ameloblastoma is the most frequently encountered tumor arising from odontogenic epithelium. It is characterized by a benign but locally invasive behavior with a high recurrence rate $(4,5)$. The clinical course of

Ameloblastoma is difficult to predict because there are no features to aid in the evaluation of the biological behavior of this tumor (6).

A probable explanation for this could be the presence of stem cells which hypothesizing that odontogenic lesions contain a small population of such cells, that have three important properties which are self-renewal, colony formation and pluripotency $(7,8)$. Stem cells are unspecialized cells defined as clonogenic cells that have the capacity for self-renewal and the potential to differentiate into one or more mature cellular lineages $(9,10)$.
Stem cell markers such as the octamer-binding transcription factor 4 (OCT4) and the sex-determining region Y (SRY)-box 2 (SOX2) are capable of identifying these stem cells expressed during the early stages of tooth development (dental papilla and dental lamina cells) (11).

SOX2 is a stem cell marker that can be used as a marker for dental epithelial stem and progenitor cells during tooth renewal and replacement. It is also a specific and sensitive marker for high-grade lesions so it can differentiate easily between malignant, aggressive benign and benign lesions (5).

\section{MATERIALS AND METHODS}

The study was performed in the Oral Pathology Department, Faculty of Dentistry, Alexandria University after gaining the approval of the Research Ethics Committee. Thirty surgical specimens were collected from patients diagnosed as benign and malignant epithelial odontogenic tumors included in this study. These cases were collected from the available cases in the Maxillofacial and Plastic Surgery Department as well as retrospective cases from files of Oral Pathology Department, Faculty of Dentistry, Alexandria University. Moreover, five specimens of normal tooth germ were taken from Oral Biology Department, Faculty of Dentistry, Alexandria University as a control group. A written informed consent was obtained from all the patients included in this study and few patients agreed to be photographed before surgery. 
The research protocol was approved by the Ethical Committee of the Faculty of Dentistry, Alexandria University.

The specimens were fixed in $10 \%$ neutral buffered formalin, processed and embedded in paraffin wax using the conventional procedures. Serial sections of 3-4 $\mu \mathrm{m}$ thickness were placed on glass slides and stained using Hematoxylin and Eosin stains (H\&E). Immunohistochemical (IHC) staining using SOX2 antibody (Biocare medical, 4040 Concord CA 94520, USA) was also performed using the Labeled Strept-Avidin Biotin complex method (LSAB). Then, the sections were examined by the image analyzer computer system using the software Leica Qwin 500.

\section{Statistical analysis}

The difference in the mean area percent and mean optical density of SOX2 in benign and malignant OTs samples in the different tumors were estimated using the student's $t$ test.

The difference in the mean area percent and mean optical density of SOX2 between OTs and control group were estimated using the student's t test. A (P) value less than 0.05 was considered significant. The values were given as a mean value \pm SD (standard deviation).

\section{RESULTS}

\section{Clinical Results}

The age of the patients included in this study ranged between 6 and 60 years. The mean age was found to be $38.73 \pm 20.70$. The median age was 45 years. Twenty patients $(66.7 \%)$ were males and ten patients (33.3\%) were females. Twenty lesions of studied cases were found in mandible and ten lesions were found in maxilla (anterior and posterior).

\section{Histopathological Results}

The microscopical examination revealed that the thirty cases (30) of the odontogenic tumors consisted of 21 benign odontogenic tumors and 9 malignant odontogenic tumors. The diagnosed cases are summarized in Table 1.

Table (1): Histopathological type of the examined cases of OTs:

\begin{tabular}{||l|c|}
\hline \multicolumn{1}{|c|}{ Odontogenic tumor } & $\begin{array}{c}\text { Number of } \\
\text { cases }\end{array}$ \\
\hline Follicular ameloblastoma & $\mathbf{3}$ \\
\hline Plexiform ameloblastoma & $\mathbf{3}$ \\
\hline Ameloblastic fibroma & $\mathbf{3}$ \\
\hline Compound odontome & $\mathbf{1}$ \\
\hline Ghost cell tumor & $\mathbf{1}$ \\
\hline Pindborg tumor & $\mathbf{2}$ \\
\hline Adenomatoid odontogenic tumor & $\mathbf{2}$ \\
\hline Hybrid tumor & $\mathbf{2}$ \\
\hline Unicystic ameloblastoma & $\mathbf{3}$ \\
\hline Squamous odontogenic tumor & $\mathbf{1}$ \\
\hline Ameloblastic carcinoma & $\mathbf{8}$ \\
\hline Ameloblastic fibrosarcoma & $\mathbf{1}$ \\
\hline
\end{tabular}

\section{Immunohistochemical Results}

All cases of normal tooth germ tissues $(n=5)$ showed mild immune-reactivity for SOX2 (Figure 1). Malignant OTs biopsies $(n=9)$ showed both cytoplasmic and nuclear intense immunoreactions. Mild nuclear SOX2 immunosignaling was detected in the aggressive OTs. (Figures 2, 3, 4, 5, and 6)

The IHC staining intensity was found to be directly proportional to the state of aggressiveness of OTs. The malignant OTs showed the highest staining intensity, followed by the aggressive OTs, while negative immuneexpression was found in benign OTs.

Comparison between immunoexpression of control and OTs cases in SOX2

A greater mean optical density was recorded in OTs cases compared to the control cases.

Student's t test revealed that the difference was statistically significant $(\mathrm{P}>0.05)$ (Table 3$)$. Similarly, a greater mean area percent was recorded in OTs cases compared to control. However, student's t test revealed that the difference didn't reach the level of statistical significance ( $\mathrm{P}>0.05$ ) (Table 2).

Table (2): Comparison of area percent and optical density of SOX2 in control and OTs cases:

\begin{tabular}{|c|c|c|c|c|}
\hline Receptor & $\begin{array}{c}\text { Point of } \\
\text { comparison }\end{array}$ & $\begin{array}{c}\text { OTs } \\
(n=30)\end{array}$ & $\begin{array}{c}\text { Control } \\
(n=5)\end{array}$ & $\begin{array}{l}\text { P value } \\
\text { (Student's } \\
\text { test) }\end{array}$ \\
\hline SOX2 & $\begin{array}{c}\begin{array}{c}\text { Optical } \\
\text { density }\end{array} \\
\text { Min. -Max. } \\
\text { Mean } \pm S D \text {. }\end{array}$ & $\begin{array}{l}3.62-54.01 \\
23.24 \pm 18.02\end{array}$ & $\begin{array}{l}4.45-8.37 \\
6.43 \pm 1.58\end{array}$ & $0.012^{*}$ \\
\hline & $\begin{array}{c}\text { Area } \\
\text { percentage } \\
\text { Min. -Max. } \\
\text { Mean } \pm \text { SD. }\end{array}$ & $\begin{array}{l}15.14-69.80 \\
40.73 \pm 15.86\end{array}$ & $\begin{array}{l}30.46-36.71 \\
33.14 \pm 2.36\end{array}$ & $0.637 \mathrm{~ns}$ \\
\hline
\end{tabular}

*Statistically significant, ns=non-significant.

Comparison between immunoexpression of benign and malignant OTs cases in SOX2

Both area percent and the optical density were greater in malignant OTs $(n=9)$ cases compared to the benign OTs cases $(n=21)$. Student's t test revealed that the difference was statistically significant $(\mathrm{P}<0.05)$ (Table 3$)$.

Table (3): Comparison of area percent and optical Density of SOX2 in OTs cases $(n=30)$

\begin{tabular}{|c|c|c|c|c|}
\hline \multirow{2}{*}{ Receptor } & \multirow{2}{*}{$\begin{array}{c}\text { Point of } \\
\text { comparison }\end{array}$} & \multicolumn{2}{|c|}{ Type of tumor } & \multirow{2}{*}{$\begin{array}{c}\text { P value } \\
\text { (Student's } \\
\text { test) }\end{array}$} \\
\hline & & $\begin{array}{l}\text { Benign } \\
(\mathrm{n}=21)\end{array}$ & $\begin{array}{c}\text { Malignant } \\
(\mathrm{n}=9)\end{array}$ & \\
\hline \multirow{6}{*}{ SOX2 } & $\begin{array}{l}\text { Optical } \\
\text { density }\end{array}$ & & & \multirow{3}{*}{$<0.001^{*}$} \\
\hline & Min.-Max. & $3.62-18.26$ & $41.65-54.01$ & \\
\hline & Mean \pm SD. & $12.04 \pm 5.05$ & $49.40 \pm 3.78$ & \\
\hline & $\begin{array}{c}\text { Area } \\
\text { percentage }\end{array}$ & & & \multirow{3}{*}{$<0.001^{*}$} \\
\hline & Min.-Max. & $15.14-41.33$ & $53.38-69.80$ & \\
\hline & Mean \pm SD & $31.17 \pm 5.81$ & $63.04 \pm 5.21$ & \\
\hline
\end{tabular}

*Statistically significant 


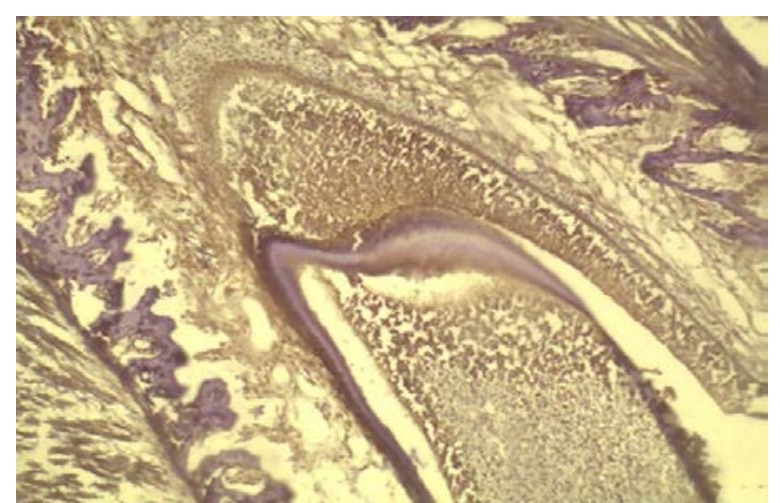

Figure (1): Normal tooth germ Showing mild Immunereactivity for SOX2 (Immuno stain of SOX2 x200).

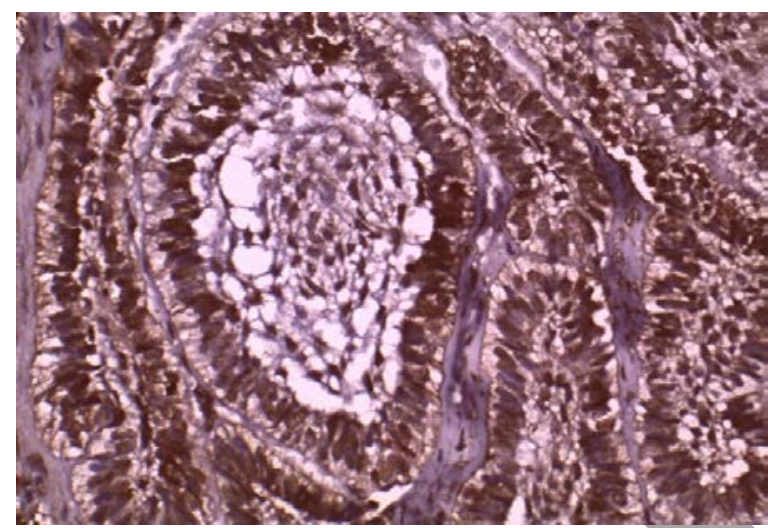

Figure (2): Ameloblastic fibrosarcoma revealing intense nuclear SOX2 immunosignals in the epithelial and spindle cells (x400).

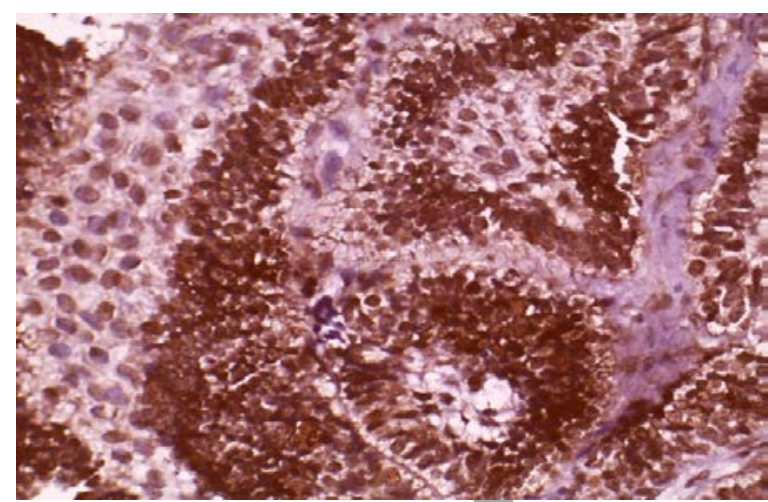

Figure (3): Ameloblastic carcinoma revealing intense nuclear immunosignals of SOX2 in the ameloblast like cells. Faint cytoplasmic reaction is noted. The connective tissue stroma is devoid fromany reaction (x400).

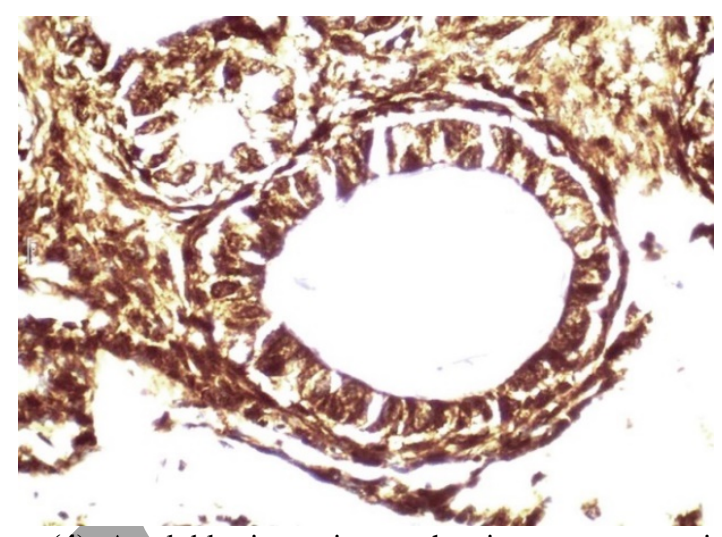

Figure (4): Ameloblastic carcinoma showing sever expression of SOX2 in malignant epithelial cells and loss of normal configuration (x400).

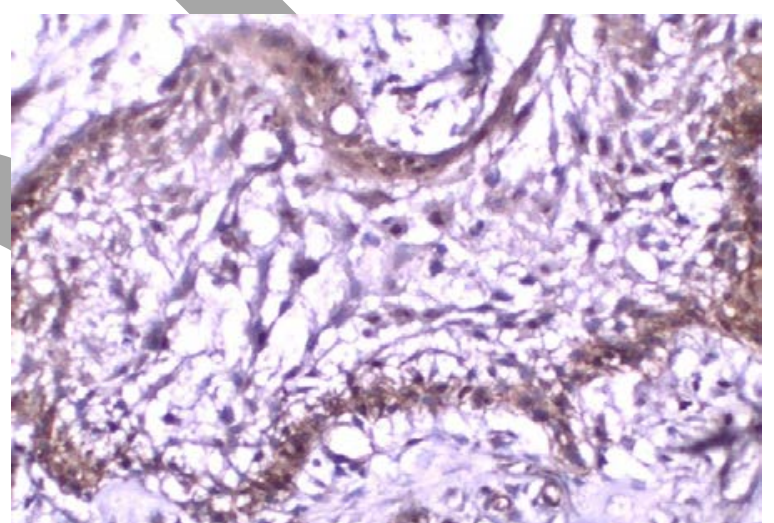

Figure (5): Adenomatiod odontogenic tumor showing mild expresstion of Sox2 (X400)

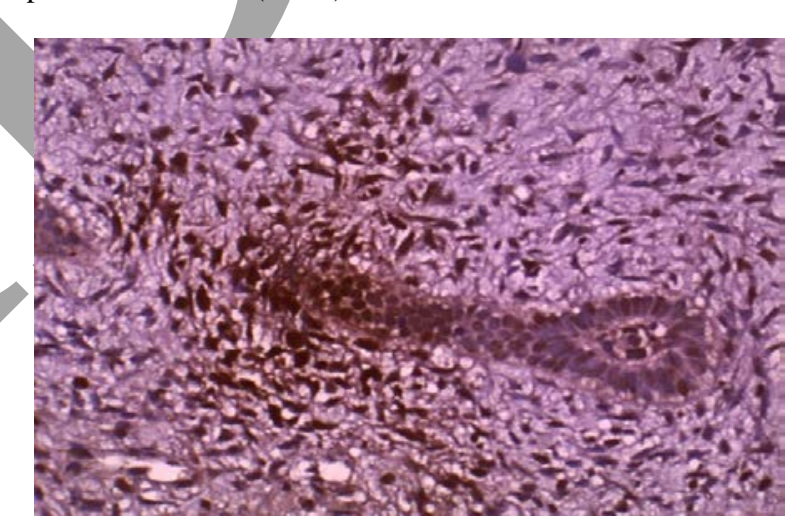

Figure (6): Squamous odontogenic tumor showing negative expression of Sox2 (x400).

\section{DISCUSSION}

Embryonic stem cells (ESCs) are defined as cells that have their ability to self-renewal and to differentiate into a variety of adult tissues and cell types. It is generally considered that SOX2, OCT4 and Nanog are key transcription regulators that maintain the pluripotency and self-renewal properties of ESCs $(12,13)$. Growing data demonstrates that expression of SOX2, OCT4 and Nanog could promote tumor cell growth, anti-apoptosis and metastasis in vitro and in vivo, therefore play an important role in carcinogenesis $(14,15)$. An important finding was that, these ESCs-associated proteins were highly expressed in various cancers and 
contributed to tumor aggressiveness and poor outcome (16, 17).

SOX2 family of transcription factors or sex determining region (SRY) carries a characteristic highmobility group (HMG) domain that binds DNA in a sequence-specific manner and those proteins, which contain a HMG domain with $50 \%$ or higher amino acids in similarity to the HMG domain of SRY are referred to as SOX proteins. SOX factors play a very important role to play in the development, tissue homeostasis, reprogramming, and cancer (12).

SOX2 was investigated in different kinds of neoplastic and preneoplastic lesions all over the body. Such as in the cancer of lung, colon, breast, liver and ovary as well as preneoplastic lesions as polyps of colon and breast adenomas and the effect it has on their clinical and histopathological features (18-22). However, very few studies investigated SOX2 in odontogenic tumors.

In the present work, among the 30 examined cases of odontogenic tumors, 30\% were ameloblastomas (9 cases). This coincides with Melrose (23), Kramer et al. (3) and Sciubba et al. (4), who stated that ameloblastoma was the most frequently encountered tumor arising from the odontogenic epithelium.

In the present research, other than the ameloblastoma, $40 \%$ (12 cases) (of the odontogenic tumors were benign tumors. These tumors were ameloblastic fibroma (10\%) (3 cases), adenomatoid odontogenic tumor (AOT), hybrid tumor and pindborg tumor (6,6\%) (2 cases) each, as well as ghost cell tumor, squamous odontogenic tumor and odontoma (1 case) each. This goes with the results of Taylor who mentioned that the second category of their examined series of odontogenic tumors included AOT, pindborg tumor and ghost cell tumor (24).

In the present study, malignant odontogenic tumors (30\%) (9 cases) were confined to ameloblastic carcinoma (26,6\%) (8 cases) and ameloblastic fibrosarcoma (3,3\%) (1 case). There were slight variation in percentage between this study and others studies done on African and Latin American populations. This may be due to differences in the racial and regional distribution of odontogenic tumors. Another difference may also be due to the lack of uniform criteria employed in most of the previously published works, since although some authors used criteria based on WHO classification others used different definitions (24).

In the present work, the radiographic appearance of the examined cases revealed a wide range of radiolucencies. All types of ameloblastoma except the unilocular type revealed multilocular radiolucencies (honey combed or soap bubble appearance) and in many cases an impacted lower wisdom is associated with the radiolucent defect, while in case of the unicyctic ameloblastoma, well defined unilocular radiolucency appeared. The pindborg tumor and AOT appeared as a mixed radiolucent and radiopaque lesion. Furthermore, ameloblastic carcinoma is more aggressive with ill-defined margins and cortical destruction. This is in accordance with the radiographic pictures mentioned by the World Health Organization (WHO) in 2017 and many text books (11).
In this immunohistochemical study, SOX2 showed intense nuclear and cytoplasmic expression of $30 \%$ of the examined odontogenic tumors (malignant), where it showed mild expression in atypical ameloblastoma (aggressive) this may be due to showing some degree of cytologic atypia, increased cellularity and loss of ameloblastic differentiation in focal areas. SOX2 was not expressed in the other benign odontogenic tumors.

As control, 5 specimens of normal tooth germs taken from Oral Biology Department, Faculty of Dentistry, Alexandria University have been examined for the presence of SOX2. All were moderately stained with SOX2. This agrees with the results reported in the work done by Kero et al. (25) Juuri et al. (26). In our study, we observed a similar pattern, with SOX2 expression usually being restricted to the cells in inner and outer enamel epithelium layers, suggesting that SOX2 protein plays a role in maintaining the physiologic turnover of dental lamina. Additionally, SOX2 was detected in budding epithelium at the distal region of the third molar. This is the site for the formation of a fourth molar that most humans have lost in the course of evolution. Contradictory results were found by Jumana et al. (25).

In our study, we found that majority of ameloblast like cells in examined cases of ameloblastoma were negative for SOX2, while some revealed mild expression of SOX2 marker. This goes with the results of Qiao et al. (27) which found the expression of SOX2 to be proportional to the progression of the disease in their study conducted on transforming oral mucosa. They stated that in focal areas that showed some degree of cytologic atypia, increased cellularity, and loss of ameloblastic differentiation, SOX2 was strongly positive in aggregation of tumor cells. This may be due to the locally invasive behavior of ameloblastoma.

On the other hand, Juuri et al. (26) stated that SOX2 is highly expressed in ameloblastomas and in the dental lamina and its fragments associated with the developing third molar. However, in our work we only detected mild to moderate expression of SOX2 in atypical ameloblastoma.

In the current study, $30 \%$ of the ameloblastomas were of the unicystic type. They all showed mild immunosignals to the SOX2 marker. The reaction was mainly in the ameloblast like cells in both luminal and intraluminal subtypes suggesting a less aggressive behavior. This is in accordance with results of Sandra et al. (28). They reported that the proliferation index of the unicystic type of ameloblastoma is lower than in the conventional ameloblastomas. Thus it was believed to be clinically less aggressive and successfully treated by enucleation and curettage.

They interestingly stated that all of the peripheral layers of ameloblastomatous follicles were stained intensely by SOX2. Moreover, some investigators suggested that the growth of ameloblastoma occurs mostly in the peripheral parts of the neoplastic islands, in the cells that morphologically resemble preameloblasts or 
ameloblast-like cells (28). This explains the positive reaction to SOX2 in the two cases of AOT.

In our study, two cases of hybrid tumor were investigated. One of them showed positive immunereactivity to SOX2 with variable intensities and the other case showed negative expression of SOX2. When we do further research, we found that the positive case was recurrent hybrid tumor with aggressive behavior .To most of our knowledge, no research was performed on stem cell marker in hybrid tumor.

The mixed odontogenic tumors are tumors which consist of both neoplastic epithelial components and neoplastic ectomesenchymal components. Ameloblastic fibroma is a mixed tumor composed of proliferating ameloblastic follicles within a cellular primitive stroma. Both the fibromatous portion of the tumor and ameloblastic follicles showed negative expression of SOX2. As far as we know, no work was done on the significance of stem cell markers in the pathogenesis of ameloblastic fibroma.

SOX2 is one of the most cancer-specific proteins identified to date, being upregulated in almost all human tumors. This was in accordance with the studies conducted by some authors that stated that SOX2 is expressed in many cancer/tumor-initiating stem cells (25), and that it involved in several steps of tumor formation $(22,29,30)$. Moreover, an increased copy number of SOX2 has been identified in many cancers, including oral cancer (31, 32). We suggest that SOX2 is associated with proliferation of the tumor epithelium in odontogenic tumors and that ameloblastic carcinoma may originate from SOX2 positive cells. That would agree well with the recent demonstration of a stemcell origin of tumors in other epithelial organs: the intestinal crypt stem cells give rise to intestinal adenomas (33) and hair follicle stem cells contribute to tumor development in epidermis (34). In light of these findings and the established functions of SOX2 in embryonic, adult, and cancer/tumor stem cells, we suggest that SOX2 regulates stem-cell maintenance in odontogenic epithelium.

In the present work, 9 cases of malignant odontogenic tumor (30\%) were examined for the presence of SOX2 protein. Among those, one case was ameloblastic fibrosarcoma (3\%), which showed intense immunosignals to SOX2 in both the ameloblastic and sarcomatous portion of the tumor. Which indicate its aggressive behavior and due to this, it could be diagnosed as an ameloblastic carcinosarcoma. Similarly,a study performed by Mary et al. showed intense expression of SOX2 in the sarcomatous portion and weak expression in the ameloblastic portion (35).

Diagnostic dilemma in ameloblastic lesions often arises in two scenarios: (1) the cytologic atypia and loss of ameloblastic differentiation are intermediate, and cannot be easily categorized into either aggressive ameloblastoma (AA) or ameloblastic carcinoma (AC); or (2) depending on the relative extent of the cytologic atypia and high-grade transformation, confusing overlapping histologic features exist between AA and AC (36). The histologic features of AA fall into the intermediate category compared with $\mathrm{AB}$ and AC. The criteria used to establish a diagnosis of AA in this study included (1) focal loss of classic ameloblastic differentiation; (2) increased crowding and cytologic pleomorphism (but no area should show a mitotic count of 2 or more per high-power field); and (3) absence of angiolymphatic or perineural invasion.

The term ameloblastic carcinoma (AC) refers to malignant odontogenic neoplasm with histologic features of ameloblastoma with overtly malignant cytologic features, regardless of the presence or absence of metastasis (37). Features of malignancy would include nuclear pleomorphism, readily identified mitotic activity mitoses in a high power field in a high grade area (2), focal necrosis and nuclear hyperchromatism (38). AC is rare with 100 cases in the literature $(36,38,39)$. The demographics of AC are similar to ameloblastoma, located most often in the posterior mandible and both genders affected equally, but $\mathrm{AC}$ is primarily seen in the elderly. The majority of AC appears to develop de novo, but rare cases develop in pre-existing ameloblastoma (recurrent) $(36,38)$.

In our present study, 8 cases of ameloblastic carcinoma (26\%) were examined for the presence of SOX2 protein. All of them showed an intense SOX2 immune-staining pattern. SOX2 overexpression was observed in both the nuclei and the cytoplasm of all of the ameloblastic follicles. These results were in consistence with the studies conducted by Qiao et al. (27) and Banerjee A et al. (40). In their work on ameloblastic carcinoma, showed that SOX2 was observed in $100 \%$ of the tumor tissue samples in cases of ameloblastic carcinoma (40). In our study, we consistently found strong nuclear and cytoplasmic positivity of SOX2 in AC.

Multiple studies detected high levels of SOX2 produced by the tumor cells in different types of malignancy. Lei et al. (30) reported the expression of SOX2 protein within cases of ameloblastic carcinoma. Qiao et al. (27) found the expression of SOX2 to be proportional to the progression of the disease in their study conducted on ameloblastic carcinoma. In our study, we consistently found strong nuclear and cytoplasmic positivity of SOX2 in AC, in comparison with only scattered positivity in the benign counterparts. Therefore, we concluded that SOX2 staining could serve as a useful marker to highlight areas undergoing high-grade transformation in an atypical ameloblastoma.

\section{CONCLUSIONS}

SOX2 could be a specific and sensitive marker for highgrade ameloblastic neoplasms. SOX2 is detected immunohistochemically in malignant and aggressive OTs biopsies. The intensity of its expression is directly proportional to the state of aggressiveness of the OTs. SOX2 could have great promise in research involving induced pluripotency, an emerging and very promising field of regenerative medicine. 


\section{CONFLICT OF INTEREST}

The authors declare that they have no conflicts of interest.

\section{REFERENCES}

1. Ochsenius G, Ortega A, Godoy L, Penafiel C, Escobar E. Odontogenic tumors in Chile: a study of 362 cases. J Oral Pathol Med. 2002; 31:415-20.

2. Fernandes AM, Duarte EC, Pimenta EJ, Souza L, Santos V, Souza L, et al. Odontogenic tumors: a study of 340 cases in Brazilian population. J Oral Pathol Med. 2005; 34:583-7.

3. Kramer IRH, Pindborg JJ, Shear M. WHO histological typing of odontogenic tumors. $2^{\text {nd }}$ ed. Berlin: Springer; 1992. p 11-27.

4. Scuibba JJ, Fantasia JE, Kahn LB. Tumors and cysts of the jaw. Washington DC: Atlas of tumor pathology, $3^{\text {rd }}$ series, Armed Forces Institute of Pathology; 2001. p 71-99.

5. Leon Banes, John W, Eveson, Peter Reichart, Sidransky D. Pathology and genetics of head and neck tumors. In: Paul Kleihues MD, Leslie H. Sobin MD (eds). Lyon: IARC Press International Agency for Research on Cancer (IARC) 69008; 2005.

6. McClatchy KD. Tumors of the dental lamina: A selective review. Semin Diagn Pathol. 1987; 4:200-4.

7. Simpson HE. The degeneration of the rests of malassez with age as observed by apoxestic technique. J Periodontal. 1965; 36:288-91.

8. Nery EB, Kraus BS, Croup M. Timing and topography of early human tooth development. Arch Oral Biol. 1970;15:1315-26.

9. Mjor LA, Fejerskov O. Histology of the human tooth. $2^{\text {nd }}$ ed. Copenhagen: Munksgaard; 1979.

10. Norberg O. Studies of the human jaws and teeth. Z Anat Entwicklungsgesch. 1960; 122:1-21.

11.El-Naggar AK, Chan JKC, Grandis JR, Takata T, Slootweg PJ. WHO classification of head and neck tumours. $4^{\text {th }}$ ed. 2017. P 204-60.

12. Avilion AA, Nicolis SK, Pevny LH, Perez L, Vivian N, Lovell-Badge R. Multipotent cell lineages in early mouse development depend on SOX2 function. Genes Dev. 2003; 17:126-40.

13. Mitsui K, Tokuzawa Y, Itoh H, Segawa K, Murakami M, Takahashi K, et al. The homeoprotein Nanog is required for maintenance of pluripotency in mouse epiblast and ES cells. Cell. 2003; 113:631-42.

14. Ferletta M, Caglayan D, Mokvist L, Jiang Y, Kastemar M, Uhrbom L, et al. Forced expression of Sox21 inhibits Sox2 and induces apoptosis in human glioma cells. Int J Cancer. 2011; 129:45-60.

15. Han J, Zhang F, Yu M, Zhao P, Ji W, Zhang H, et al. RNA interference-mediated silencing of NANOG reduces cell proliferation and induces G0/G1 cell cycle arrest in breast cancer cells. Cancer Lett. 2012; 321:80-8.

16. Leis O, Eguiara A, Lopez-Arribillaga E, Alberdi MJ, Hernandez-Garcia S, Elorriaga K, et al. Sox2 expression in breast tumours and activation in breast cancer stem cells. Oncogene. 2012; 31:1354-65.
17. Jeter CR, Liu B, Liu X, Chen X, Liu C, Calhoun-Davis T, et al. NANOG promotes cancer stem cell characteristics and prostate cancer resistance to androgen deprivation. Oncogene. 2011; 30:3833-45.

18. Lazarus K, Hadi F, Zambon E, Bach K, Santolla MF, Watson JK, et al. PO-086 BCL11A interacts with SOX2 to control the expression of epigenetic regulators in lung squamous cell carcinoma. Nat Commun. 2018; 9:3327.

19. Talebi A, Kianersi K, Beiraghdar M. Comparison of gene expression of SOX2 and OCT4 in normal tissue, polyps, and colon adenocarcinoma using immunohistochemical staining. Adv Biomed Res. 2015; 4:234.

20. Lengerke C, Fehm T, Kurth R, Neubauer H, Scheble V, Müller F, et al. Expression of the embryonic stem cell marker SOX2 in early-stage breast carcinoma. BMC Cancer. 2011; 11:42.

21. Kim BW, Cho H, Choi CH, Ylaya K, Chung JY, Kim JH, et al. Clinical significance of OCT4 and SOX2 protein expression in cervical cancer. BMC Cancer. 2015; 15:1015.

22. Sanada Y, Yoshida K, Ohara M, Oeda M, Konishi K, Tsutani Y. Histopathologic evaluation of stepwise progression of pancreatic carcinoma with immunohistochernical analysis of gastric epithelial transcription factor SOX2 - Comparison of expression patterns between invasive components and cancerous or nonneoplastic intraductal components. Pancreas. 2006,32:164-70.

23. Melrose RJ. Benign epithelial odontogenic tumors. Semin Diagn Pathol. 1999; 37; 296-300.

24. Mosqueda-Taylor A, Menesses GA, Ruiz Gody LM, Suarez RM, Luna O. Malignant odontogenic tumors. A retrospective study of 7 cases. Med Oral. 2003; 8:110-21.

25. Kero D, Novakovic J, Vukojevic K, Petricevic J, Kalibovic Govorko D, Biocina-Lukenda D, et al. Expression of Ki67, Oct-4, $\gamma$-tubulin and $\alpha$-tubulin in human tooth development. Arch Oral Bio. 2014; 59:1119-29.

26. Juuri E, Isaksson S, Jussila M, Heikinheimo K, Thesleff I. Expression of the stem cell marker, SOX2, in ameloblastoma and dental epithelium. Eur J Oral Sci. 2013; 121:509-16.

27. Qiao B, He B, Cai J, Yang W. The expression profile of Oct 4 and Sox2 in the carcinogenesis of oral mucosa. Int $\mathrm{J}$ Clin Exp Pathol. 2014;7:28-37.

28. Sandra F, Nakamura N, Mitsuyasu T, Shiratsuchi Y, Ohishi M. Two relativity distinct patterns of ameloblastoma: an anti-apoptotic proliferating site in the outer layer (periphery) and a pro-apoptotic differentiating site in the inner layer (center). Histopathology. 2001; 39:93-8.

29. Chiou SH, Wang ML, Chou YT, Chen CJ, Hong CF, Hsieh WJ, et al. Coexpression of Oct4 and nanog enhances malignancy in lung adenocarcinoma by inducing cancer stem cell-likeproperties and epithelial-mesenchymal transdifferentiation. Cancer Res. 2010; 70:10433-44.

30. Lei Y, Jaradat JM, Owosho A, Adebiyi KE, Lybrand KS, Neville BW, et al. Evaluation of SOX2 as a potential marker for ameloblastic carcinoma. Oral Surg Oral Med Oral Pathol Oral Radiol. 2014; 117:608-16.e1. 
31. Bass AJ, Watanabe $\mathrm{H}$, Mermel $\mathrm{CH}$, Yu S, Perner S, Verhaak RG, et al. SOX2 is an amplified lineage-survival oncogene in lung and esophageal squamous cell carcinomas. Nat Genet. 2009; 41:1238-42.

32. Freier K, Knoepfle K, Flechtenmacher C, Pungs S, Devens $F$, Toedt G, et al. Recurrent copy number gain of transcription factor SOX2 and corresponding high protein expression in oral squamous cell carcinoma. Genes Chromosom Cancer. 2010; 49:9-16.

33. Schepers AG, Snippert HJ, Stange DE, van den Born M, van Es $\mathrm{JH}$, van de Wetering $\mathbf{M}$, et al. Lineage tracing reveals lgr5+ stem cell activity in mouse intestinal adenomas. Science. 2012; 337:730-5.

34. Da Silva-Diz V, Solé-Sánchez S, Valdés-Gutiérrez A, Urpí M, Riba-Artés D, Penin RM, Progeny of lgr5-expressing hair follicle stem cell contributes to papillomavirusinduced tumor development in epidermis. Oncogene. 2013; 32:3732-43.

35. Mary S, Muller S. Malignant Odontogenic Tumors: An Update on Selected Tumors. Head and Neck Pathol. 2014; 8:411-20.

36. Woolgar JA, Triantafyllou A, Ferlito A, Devaney KO, Lewis JS Jr, Rinaldo A, et al. Intraosseous carcinoma of the jaws: a clinicopathologic review, part I: odontogenic carcinomas. Head Neck. 2013; 35:902-5.

37. Barnes L, Eveson J, Reichart P, Sidransky D. World Health Organization classification of tumours: pathology and genetics of head and neck tumours. Lyon: IARC Press; 2005. p 284-91.

38. Hall JM, Weathers DR, Krishnan K. Ameloblastic carcinoma: an analysis of 14 cases. Oral Surg Oral Med Oral Pathol Oral Radiol Endodontol. 2007; 103:799-807.

39. Yoon H-J, Hong S-P, Lee J-I. Ameloblastic carcinoma: an analysis of 6 cases with review of the literature. Oral Surg Oral Med Oral Pathol Oral Radiol Endodontol. 2009;108:904-13.

40. Banerjee A, Kamath VV, Sundaram L, Krishnamurthy SS. OCT4 and SOX2 are reliable markers in detecting stem cells in odontogenic lesions. J Orofac Sci. 2016; 8:16-21.
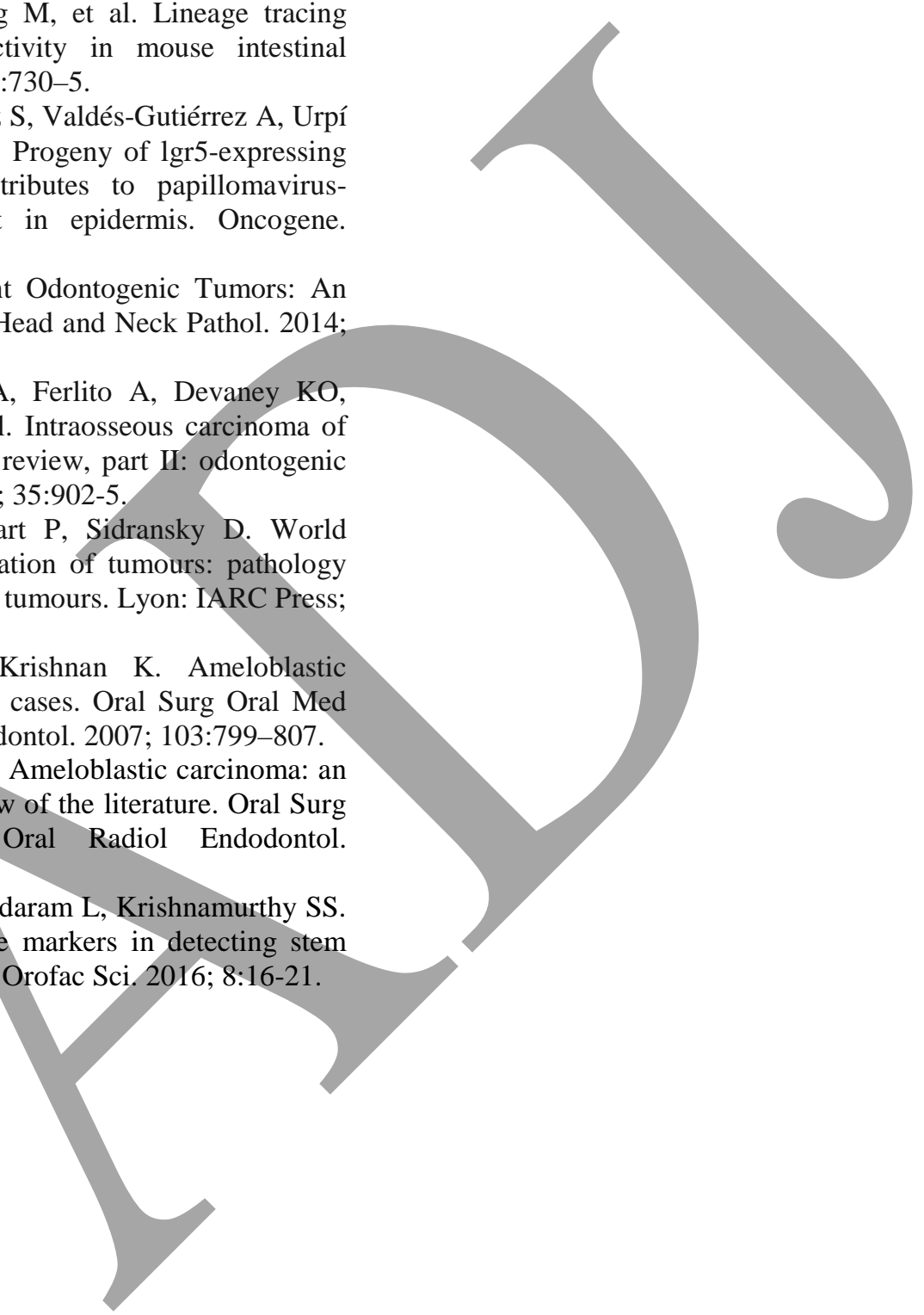